\title{
Effects of Palm Oil Sludge Supplementation in Starter Diets of Broiler Chickens on Growth Performance, Economic Analysis, Feed Conversion and Skin Pigmentation.
}

\author{
Uche D.E. Ogbuokiri Vitus Izuazu Maxwell Edih Callistus A. Marcus \\ Department of Animal Production and Health Technology, Imo State Polytechnic Umuagwo, Ohaji, Owerri, Nigeria \\ Colman Ibe \\ Department of Science Laboratory Technology, Imo State Polytechnic, Umuagwo, PMB 1472, Ohaji, Owerri, Nigeria
}

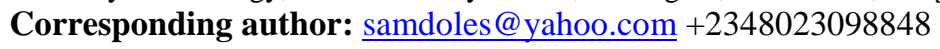

\begin{abstract}
The effects of dietary palm oil sludge supplementation on growth performance, economic analysis, feed conversion and skin pigmentation of broiler starter chickens were investigated in a 21-day feeding trial. One hundred and twenty (120) Cobb broiler chicks selected from a pool of 150 day-old broiler chicks of mixed sexes (straight-run) on basis of vigor were used for this experiment. They were reared from day old to one week of age following standard procedures and strict bio-security measures, using commercial feed before being randomly divided into five groups of 24 birds each. They were assigned to five treatment diets containing $0 \%$ (control), $2.5 \%, 5 \%, 10 \%$ and $12.5 \%$ dietary palm oil sludge. Each group was further divided into four replicates of six birds each in a completely randomized design (CRD). Treatment 5 had better mean daily weight gain/bird (g) than treatments 1,2 and 3 . The weight gain got better with the increase in the percentage inclusion rate from treatment $2(2.5 \%)$ to treatment $5(12.5 \%)$. The mean daily feed intake of birds in treatments 4 and 5 were higher than those of the other treatments. The feed conversion ratio was not significant $(p>0.05)$ for all the treatments. The economics of production shows that the feed cost was highest for treatment 1 (N64.56) and decreased with increasing levels of dietary palm oil sludge supplementation in treatments 4 and 5 with N58.44 each. This suggests that dietary palm oil sludge supplementation would be economical and also cost-effective. Shank pigmentation scores show a high positive correlation between color scores of the shank and additive amounts of palm oil sludge.
\end{abstract}

Keywords: Palm oil sludge, starter broiler, performance, shank pigmentation

\section{Introduction}

One of the major problems facing the development of the animal industry is the limited availability and high cost of feedstuffs (Adeniji and Jimoh, 2007). This is, in part, due to stiff competition for conventional feedstuffs between livestock and human (Adeniji and Jimoh, 2007; Adeniji and Onyeleke, 2008). Maize, a cereal, is an important source of energy in both livestock and human nutrition. It makes up more than one-third of the finished feed for poultry but due to its high prices, it is becoming more expensive to use at high levels in poultry feeds. Researchers put the contribution of feed in livestock production within the range of about $60-70 \%$ (Ranjhnan, 2001) and 70-80\% Devendra and Fuller (1979). This situation has led to stagnation of growth in the industry, resulting in an average Nigerian consuming $7.5 \mathrm{~g}$ of protein per head/day which is below the $27 \mathrm{~g} / \mathrm{head} /$ day recommended by FAO (Emaikwu et al. 2011). This pitiable situation is because the domestic supply of animal protein grows at 1.8 percent per annum, while demand is rising at 5.1 percent annually resulting in an acute scarcity of the product (FAO, 2009). This imposed serious constraints on the ability of the people to take the product for healthy living (FAO, 2009). According to Abdulmojeed et al. (2010), the quickest potential for bridging protein supply-demand gap lies in the production of highly prolific animals that are efficient converters of feed to flesh, have short generation interval such as broilers and the integration of the wide array of cheap and locally available non-conventional feedstuffs at our disposal into well-defined feeding systems to reduce cost. The non-conventional feedstuffs refer to all those feedstuff that have not been traditionally used in animal feeding and or are not normally used in commercially produced rations for livestock.

Therefore, exploring the use of alternative energy materials such as palm oil sludge as an energy source in pigs and poultry diets makes economic sense given the rising cost of imported feedstuffs and at the same time, it would reduce pollution problems. The justification for increasing the effective utilization of non-conventional feed resources (NCFR) is associated with inadequate supplies and rising feed costs, Devendra, (1988). A further justification for this approach is that in many countries in the Region, the imbalance between the total animal resources and feed supplies is so critical that the latter is often a major limiting factor in production, Devendra, (1988). According to Devendra, 1977 and Devendra, et al, 1982, a by-product of interest in palm oil production in term of substituting energy in conventional pigs and poultry diet is palm oil sludge (POS). Palm oil sludge is the material that remains after decanting the palm oil mill effluent and can cause a problem to the entire surrounding ecosystem. It has a crude protein (CP) of $96 \mathrm{~g} / \mathrm{kg}$ and metabolizable energy (ME) of 17.76 
$\mathrm{MJ} / \mathrm{kg}$ (Devendra, 1977). This makes it relatively comparable to maize with $90 \mathrm{~g} / \mathrm{kg} \mathrm{CP}$ and an ME of 14.37 MJ/kg (Devendra, 1977). Palm oil mill exudates, therefore, seem to be good carbohydrate and protein sources for poultry feeding and means of reducing feeding cost in poultry production when properly processed (Alikwe, et al, 2011). Dada (1999) reported that $5 \%$ palm oil sludge inclusion in finishing broiler chicken diets resulted in improved performance characteristics.

The color of skin and meat of chickens is an important factor in determining consumers' preference in many countries. Pigmentation is an important factor in consumer acceptance and perceived quality of broilers (Ouart et al, 1988). According to Liu, et al., 2008; Velasco and Williams , 2011, meat quality is often evaluated based on color. The color of poultry skin is provided by carotenoid pigments present in the diet of birds that are deposited in the skin and subcutaneous fat. According to Schmidt (1998) poultry use carotenoids for pigmentation, and these substances are also involved in growth metabolism and fertility. Some carotenoids provide protection against damaging reactions in the body, acting as physiological antioxidants (Burton, 1989), and thus enhancing the immune response (Bendich, 1989). Allen et al. (1997) reported that darker broiler breast meat fillets have a shorter shelflife than lighter breast fillets; the shorter shelf-life may be due to differences in $\mathrm{pH}$. Lokaewmanee et al. (2011) reported that broilers cannot synthesize pigments. Castaneda, et al., 2005 equally reported that a typical corn and soybean-based commercial diets cannot provide adequate quantity and types of pigments to meet consumers' preference for yellow chicken products. The amounts and availability of carotenoids in poultry feed ingredients fluctuate considerably. It has, therefore, become common practice in the poultry industry to add carotenoids to the feed to assure the necessary amount for pigmentation, but also for optimal health, because a number of these compounds have vitamin A activity (Hencken, 1992). Healthy poultry absorbs pigments from their diet, which are transported in the blood to the subcutaneous fat tissues and skin, where they are stored. This process is impaired in birds afflicted with diseases, especially intestinal infections and parasitic infestations (Tyczkowski et al. 1991). Most consumers want a yellow bird because this implies that the bird is reasonably free of health problems (Sunde, 1992).

The best-known carotenoids are beta-carotene. Palm oil is rich in carotenoids, from which it derives its deep red color (Igwe and Onyegbado, 2007). According to Bruce (2015), red palm oil is the richest dietary source of pro-vitamin A carotenes (betacarotene and alpha-carotene). This high content of Vitamin A is significant in pigmentation of the yolk of the egg and skin of the poultry (Tewe, 2004). The carotenoid is also available in palm oil mill waste
(Coetezee and Motshwi, 2014). Yellow skin color in broilers claims better market acceptability and longer shelf life (Allen et al. 1997).

This study was designed to evaluate the effects of dietary palm oil sludge supplementation on growth performance, economic analysis, feed conversion and skin pigmentation of starter diets in broiler chickens.

\section{Materials and methods}

\section{Experimental site}

The study was carried out at the Poultry Unit of the Imo State Polytechnic Teaching and Research Farm, Umuagwo, Ohaji, Imo State, Nigeria. The site has the coordinates of 7001 and 0611 and $700310011 \mathrm{E}$ and 502810011 and $503010011 \mathrm{~N}$, with an average yearly rainfall of $172-190 \mathrm{~cm}$. Rainfall is uniformly distributed. It has a maximum temperature of 340C and a minimum temperature of 180C (Areola et al. 2002).

\section{Sample collection}

Fresh palm oil sludge (POS) was collected from a local palm oil processing center at Umuagwo, Ohaji, Imo State, Nigeria. It was, thereafter, dried and subjected to standard proximate analysis (AOAC, 2001) to determine the crude protein, moisture, crude protein, ash, ether extract and nitrogen-free extract (NFE) as shown in Table 1.

Table 1. Proximate composition of palm-oil sludge

\begin{tabular}{lc}
\hline Component & Percentage \\
\hline Crude Protein & 12.3 \\
Oil & 10.8 \\
Moisture & 12.4 \\
Ash & 13.5 \\
NFE & 39.1 \\
Crude Fibre & 11.9 \\
${ }^{1}$ Energy $($ Kcal/kg) & 2719 \\
\hline
\end{tabular}

${ }^{1} \mathrm{ME}(\mathrm{Kcal} / \mathrm{kg})=37 \times \% \mathrm{CP}+81,1 \times \% \mathrm{EE}+35.5 \times \% \mathrm{NFE}$ (Pauzenga, 1985)

\section{Experimental birds and design}

One hundred and twenty (120) Cobb broilers of mixed sexes were used for this study. They were reared from day old to one week of age following standard procedures and strict bio-security measures, using a commercial feed to stabilize them before placing them on experimental diets. Thereafter, 120 birds out of the 150 birds were selected from a pool of 150 birds on the basis of vigor and randomly assigned to five treatments with 24 birds per treatment in a Completely Randomized Design (CRD). Each treatment was further replicated four times with six birds per replicate. Each replicate was housed in 2 x 3 $\mathrm{m}$ pens on deep litter. The birds received water and feed ad libitum starting from 7.00 am daily for the 21 days the feeding trial lasted. 


\section{Test diets}

Five experimental test diets were formulated (Table $2)$. The POS was incorporated into the diets at $0,2.5$, 5,10 and $12.5 \%$ in treatment $1,2,3,4$ and 5 , respectively. Treatment 1 served as control.

\section{Data collection}

Both weight and shank pigmentation response parameters were measured individually at the beginning of the experiment and thereafter, on a weekly basis. Feed consumption was recorded daily on a pen basis by finding the difference between the quantity offered and the quantity of the leftover collected the following day. This was later expressed on a weekly basis. The body weight gain was determined weekly while feed conversion ratio was calculated by dividing feed intake by body weight gain. The pigmentation scores were recorded weekly using Roche Colour Fan (Vuilleumier, 1969). The cost of feed per kilogram of broiler starter diet was calculated using the current prevailing market prices of feed ingredients. Feed intake per bird for the 21 days that the birds were on the experimental diet was used to multiply the cost of feed consumed by a bird. The mean daily weight gain per bird was calculated by dividing mean weight gain by 21 days the experiment lasted. The mean daily feed intake per bird was calculated by adding all feed consumed and dividing the product by the number of birds that ate the feed. Feed cost per kilogram was calculated using the kilogram of feed fed multiplied by feed cost. The cost of production was estimated as the product of cost per kilogram weight gain and mean total weight gain. Revenue was calculated by using the price of meat per kilogram multiplied by the mean total weight gain. The difference between revenue and cost of production equals the gross margin.

Table 2. Percentage Composition of the Experimental Diets $(\mathrm{Kg})$

\begin{tabular}{|c|c|c|c|c|c|}
\hline \multirow[b]{2}{*}{ Ingredients } & \multicolumn{5}{|c|}{ Treatments } \\
\hline & $(0 \%)$ & $2(2.5 \%)$ & $3(5 \%)$ & $4(10 \%)$ & $5(12.5 \%)$ \\
\hline Maize & 46 & 42 & 42 & 42 & 42 \\
\hline Sludge & 0 & 2.5 & 5 & 10 & 12.5 \\
\hline Soya bean meal & 22.2 & 22.2 & 10.2 & 10.2 & 10 \\
\hline Oil & 2 & 2 & 2 & 2 & 2 \\
\hline Fish meal & 6 & 6 & 14 & 14 & 14 \\
\hline Wheat Offal & 19.5 & 21 & 22.5 & 17.5 & 15.2 \\
\hline Lysine & 0.25 & 0.25 & 0.25 & 0.25 & 0.25 \\
\hline Methionine & 0.25 & 0.25 & 0.25 & 0.25 & 0.25 \\
\hline Bone Meal & 2 & 2 & 2 & 2 & 2 \\
\hline Oyster Shell & 1 & 1 & 1 & 1 & 1 \\
\hline Salt & 0.25 & 0.25 & 0.25 & 0.25 & 0.25 \\
\hline Premix ${ }^{*}$ & 0.30 & 0.30 & 0.30 & 0.30 & 0.30 \\
\hline Antioxidant & 0.25 & 0.25 & 0.25 & 0.25 & 0.25 \\
\hline $\begin{array}{l}\text { TOTAL } \\
\text { Calculated Analysis }\end{array}$ & 100 & 100 & 100 & 100 & 100 \\
\hline$\overline{\text { Protein }(\%)}$ & 22 & 22 & 23 & 23 & 23 \\
\hline Energy (ME Kcal/kg) & 2879 & 2838 & 2838 & 2881 & 2900 \\
\hline Oil (\%) & 5.6 & 5.6 & 6.0 & 6.4 & 6.5 \\
\hline Crude Fibre (\%) & 4.1 & 4.4 & 4.2 & 4.3 & 4.4 \\
\hline Lysine (\%) & 1.4 & 1.4 & 1.4 & 1.4 & 1.4 \\
\hline Methionine (\%) & 0.85 & 0.85 & 0.85 & 0.85 & 0.85 \\
\hline Calcium $(\%)$ & 2.1 & 2.1 & 2.1 & 2.1 & 2.1 \\
\hline Avail. Phosphorous (\%) & 0.86 & 0.86 & 0.86 & 0.86 & 0.86 \\
\hline Feed cost/bag of feed ( & 1614 & 1505 & 1464 & 1461 & 1461 \\
\hline Feed cost/kg (\#) & 64.56 & 60.20 & 58.56 & 58.44 & 58.44 \\
\hline
\end{tabular}

*Vitamin A: 12, 000,000 iu, Vit. D3: 2,500,000 iu, Vit E: 20,0000 mg, Vit K3: 2,000 mg, Vit B1: 2,000 mg, Vit. B2: 5,000 mg, Niacin: 30,000 mg, Pantothenic Acid: 11,000 mg, Vit. B6: 4000mg, Vit. B12: 15mg, Folic Acid: 1,500mg, Biotin H2: 60mg, Choline chloride: 220,000mg, Cobalt: 200mg; Copper 3,000mg, Iron: 20,000mg, Manganese: 50,000mg, Selenium: 1,000mg, Zinc: 40,000mg, and Antioxidant: 1,250mg 


\section{Data analysis}

Data obtained from the response variables were subjected to a one-way analysis of variance (ANOVA) according to the procedure of Steel and Torrie (1980). Significantly different means were separated using Duncan Multiple Range Test as described by Gordon and Gordon (2004).

\section{Results and Discussion}

\section{Growth performance}

The effects of dietary palm oil sludge supplementation on the growth indices of starter broiler birds are presented in Table 3 . The mean daily weight gain/bird $(g)$ was not significant $(p>0.05)$ for all the treatments. The weight gain got better with an increase in the percentage inclusion rate from treatment $2(2.5 \%)$ to treatment $5(12.5 \%)$, a confirmation of the findings of Dada (1999). From this result, it may be deduced that an even better result could be obtained with a level of inclusion higher than 12.5\%. Hertrampt (1998), however, reported increased daily feed intake and daily weight gain of pigs fed palm oil sludge in place of maize at a level of $15 \%$ to $30 \%$. Feltwell and Fox (1979) found that growth may be a function of food consumption, a view shared in this experiment since the live weight of birds increases in proportion to the amount of food consumption above that needed for maintenance. The final weight and average weight gain were highest for birds on diets 4 and 5. The higher weight gain in birds on diets 4 and 5 when compared with those on control diet may be attributed to higher feed intake. The increase in feed intake with increasing inclusion levels of palm oil sludge in the diet may be as a result of improvement in taste or palatability of the diets. Poultry industries measure broiler performances using feed conversion ratio (FCR) amongst, other parameters. Feed conversion ratio is influenced by strains of birds, the energy content of the ration, room temperature and a host of other conditions (North,1984). In this study, there was no significant difference in all the treatments $(p>0.05)$. The mean daily feed intake of birds in all treatments were not significant $(\mathrm{p}>0.05)$. Appetite and energy levels are factors that influence feed intake. The mean daily feed intake regime in this study which varied from $0.119 \mathrm{~kg}$ to $0.123 \mathrm{~kg}$ per bird per day was lower than those previously reported by (Oluyemi and Robert, 2002). The mean daily weight gains of the birds in this study ranged from 0.081 to $0.090 \mathrm{~kg} /$ bird. There is a direct relationship between increased feed intake and low energy diets. The high fiber content of the feed is known to depress digestibility and reduced availability of nutrients. The low inclusion rate at various levels in treatments T2 $(2.5 \%), \mathrm{T} 3(5 \%) \mathrm{T} 4$ $(10 \%)$ and T5 (12.5\%) may have made this feed less fibrous, thus the progressive increase in the values of mean daily gain per bird. The efficiency of feed utilization decreased, as the levels of POS increased in the dietary treatments, an indication that, the birds in the control diet were less efficient in converting feed to edible meat more effectively. This tends to indicate the POS was well digested and absorbed by the birds.

Table 3. Effect of dietary palm oil sludge supplementation in starter diets of broiler on the growth indices

\begin{tabular}{llllll}
\hline & \multicolumn{5}{c}{ Treatments } \\
Ingredients & $\mathbf{1}(\mathbf{0 \%})$ & $\mathbf{2 ( 2 . 5 \% )}$ & $\mathbf{3 ( 5 \% )}$ & $\mathbf{4}(\mathbf{1 0 \%})$ & $\mathbf{5}(\mathbf{1 2 . 5 \%})$ \\
\hline Protein (\%) & 22 & 22 & 23 & 23 & 23 \\
Energy (ME Kcal/kg) & 2879 & 2838 & 2838 & 2881 & 2900 \\
Calorie/Protein Ratio & 131 & 129 & 123 & 125 & 126 \\
Lysine/Methionine Ratio & 2 & 2 & 2 & 2 & 2 \\
Shank pigmentation score & $1.0^{\mathrm{a}}$ & $1.3^{\mathrm{a}}$ & $1.8^{\mathrm{b}}$ & $2.5^{\mathrm{c}}$ & $4.3^{\mathrm{d}}$ \\
Mean Initial live weight (kg) & 0.92 & 0.92 & 0.92 & 0.92 & $0.92+$ \\
Mean Final live weight (kg) & 2.62 & 2.77 & 2.77 & 2.82 & $2.94+$ \\
Mean weight gain (kg) & 1.70 & 1.85 & 1.85 & 1.90 & $2.02+$ \\
Mean Daily Weight gain/bird (kg) & $0.081^{\mathrm{a}}$ & $0.087^{\mathrm{a}}$ & $0.088^{\mathrm{a}}$ & $0.090^{\mathrm{a}}$ & $0.090^{\mathrm{a}}$ \\
Mean Daily Feed intake/bird (kg) & $0.121^{\mathrm{a}}$ & $0.120^{\mathrm{a}}$ & $0.119^{\mathrm{a}}$ & $0.123^{\mathrm{a}}$ & $0.123^{\mathrm{a}}$ \\
Feed conversion ratio (FCR) & $1.6^{\mathrm{a}}$ & $1.4^{\mathrm{a}}$ & $1.4^{\mathrm{a}}$ & $1.3^{\mathrm{a}}$ & $1.3^{\mathrm{a}}$ \\
\hline
\end{tabular}

a, b, c, d Means on the same row bearing different superscript differ significantly $(\mathrm{P}<0.05)$,

+ Not subjected to statistical analysis. 
Table 4. Economic analysis of production of broiler starter diets with graded levels of palm oil sludge based diets

\begin{tabular}{|c|c|c|c|c|c|c|}
\hline \multirow[b]{2}{*}{ Parameters } & \multirow[b]{2}{*}{$1(0 \%)$} & \multicolumn{3}{|c|}{ Treatments } & \multirow[b]{2}{*}{$5(12.5 \%)$} & \multirow[b]{2}{*}{ SEM } \\
\hline & & $2(2.5 \%)$ & $3(5 \%)$ & $4(10 \%)$ & & \\
\hline Feed cost/kg ( & $64.56^{\mathrm{a}}$ & $60.20^{\mathrm{a}}$ & $58.56^{\mathrm{a}}$ & $58.44^{\mathrm{a}}$ & $58.44^{\mathrm{a}}$ & 1.63 \\
\hline Mean Daily Feed intake/bird (kg) & $0.121^{\mathrm{a}}$ & $0.120^{\mathrm{a}}$ & $0.119^{\mathrm{a}}$ & $0.123^{\mathrm{a}}$ & $0.123^{\mathrm{a}}$ & 0.0008 \\
\hline Feed conversion ratio & $1.6^{\mathrm{a}}$ & $1.4^{\mathrm{a}}$ & $1.4^{\mathrm{a}}$ & $1.3^{\mathrm{a}}$ & $1.3^{\mathrm{a}}$ & 0.055 \\
\hline Feed Cost/Body Weight Gain $(\mathbb{N})^{\mathrm{x}}$ & $103.30^{\mathrm{a}}$ & $84.28^{\mathrm{b}}$ & $81.98^{\mathrm{b}}$ & $75.97^{\mathrm{b}}$ & $75.97^{\mathrm{b}}$ & 5.12 \\
\hline Cost of production $(\mathbb{N})$ & $8.37^{\mathrm{a}}$ & $7.33^{\mathrm{a}}$ & $7.21^{\mathrm{a}}$ & $6.84^{\mathrm{a}}$ & $6.84^{\mathrm{a}}$ & 0.28 \\
\hline Revenue ( & $81^{\mathrm{a}}$ & $87^{\mathrm{a}}$ & $88^{\mathrm{a}}$ & $90^{\mathrm{a}}$ & $90^{\mathrm{a}}$ & 1.66 \\
\hline Gross Margin ( & $72.63^{\mathrm{a}}$ & $79.67^{\mathrm{a}}$ & $81.03^{\mathrm{a}}$ & $83.16^{\mathrm{a}}$ & $83.16^{\mathrm{a}}$ & 1.94 \\
\hline
\end{tabular}

a, b, c Means on the same row bearing different superscript differ significantly $(\mathrm{P}<0.05)$,

$\mathrm{T} 1=0 \%$ level of palm oil sludge, $\mathrm{T} 2=2.5 \%$ level of palm oil sludge, $\mathrm{T} 3=5 \%$ level of palm oil sludge $\mathrm{T} 4=$ level $10 \%$ of palm oil sludge and T5 $=12.5 \%$ level of palm oil sludge

SEM: Standard error mean

$\mathrm{x} 0.0028$ Dollars $=1$ Naira

\section{Economic analysis}

The economic analysis of the production of broiler starter diets with graded levels of palm oil sludge based diets (Table 4 ) shows that the feed cost $/ \mathrm{kg}$ was highest for treatment 1 (N64.56) and decreased with increasing levels of dietary palm oil sludge in treatments 4 and 5 (N58.44) each. The treatments were not significant $(\mathrm{p}>0.05)$ but economically, there were distinct advantages in cost reduction between the control and palm oil sludge containing diets for treatments 2, 3, 4 and 5. There was no significant difference $(\mathrm{P}>0.05)$ in mean daily feed intake/bird $(\mathrm{kg})$, feed conversion ratio and cost of production. Birds fed treatment $\mathrm{T} 1$ had the highest $(\mathrm{N} 103.3 / \mathrm{kg})$ feed cost per weight gain and were significantly better $(p<0.05)$ than the other treatments. The results are in agreement with the findings of Ayoade et al (2007) who investigated the effect of replacing sugarcane scrapping meal (SCSM) with maize on the growth performance and economics of production of rabbits and observed that there were stepwise reductions in production cost as the level of SCSM in the diet increases leading to gradual increments in profit. Again, reduction in the cost of production and feed cost per kg gain of broiler birds with an increase in the level of POS indicates the potentials of reducing the cost of producing broiler birds by the inclusion of POS in starter broiler diets. The consequent increase in savings per kg gain observed in this study might not appear to be large, but when computed for several birds could give a substantial reduction in the cost of production. This will result in increased profitability to the poultry industry in the long run (Alu et al. 2013). The values obtained for the cost of feeding the starter birds (N58.44 to $64.56 / \mathrm{kg}$ ) in this study is similar to those reported by Yusuf et al. (2009) and Alu et al. (2013).

Palm oil sludge is cheap and available in rural areas of production and inexpensive compared to cereal grains. The result shows that the cost of producing $1 \mathrm{~kg}$ of feed is higher for treatment 1 and better in treatments 4 and 5. According to Waller (2007), lowest feed cost does not produce maximum margin. The current finding does not agree with Waller's work as the treatment diets performed better than the control with the highest feed cost of N64.56 per $\mathrm{kg}$ of feed (table 4). There was no significant difference $(\mathrm{p}<0.05)$ in gross margin and revenue generated but their figures were numerically higher with an increase in the inclusion of POS. Variability in the price of the sludge could be controlled since the palm oil processors would be glad to dispose of the sludge due to the hazard they pose to the environment.

\section{Shank pigmentation scores}

A pigment is a term which designates compounds that are present naturally in feed ingredients such as corn, corn gluten meal, palm oil, grass meal and lucerne meal (Raghavan, 2001). The color of the shanks and skin of broilers and the yolk color are particularly due to a group of pigments known as xanthophylls. In most Asian countries, the degree of pigmentation in broilers and the color of the yolk are of paramount importance to consumers (Raghavan, 2001). Castaneda et al. (2005) indicated that natural pigments were generally more effective than synthetic ones in improving the yellowness of animal skin. The color of skin and meat of chickens is an important factor in determining consumers' preference in many countries. Meat quality is often evaluated based on the color. Farmers do not get a premium for producing these birds as it is only consumer preference and mark of healthy birds, but consumers could make their choice based on the belief that the birds with skin color may be healthier than their counterparts.

The result of shank pigmentation scores, using a Roche Colour Fan (Vuilleumier, 1969) are shown in table 3. From the result, there was a high positive correlation between color scores of the shank and additive amounts of palm oil sludge. The experimental 
groups deposited more yellow xanthophyll pigments than the control. Birds on treatments 4 and 5 rations had significantly better pigment $(p<0.05)$ than the rest of the treatments. But, treatment 5 had significantly better pigment $(p<0.05)$ than the rest of the treatments. Treatment 4 was significantly better $(p<0.05)$ than treatments 1,2 and 3 , while treatments 3 was significantly better $(\mathrm{p}<0.05)$ than treatments 1 and 2 . Igwe and Onyegbado (2007) noted that palm oil had a deep red color that is derived from carotenoids. This may have accounted for the high skin pigmentation scores recorded in treatments $4(10 \%)$ and $5(12.5 \%)$ given their high levels of inclusion. This supports the views of Udedibie (1987), Opara (1996), Tewe (2004); Ogbuokiri (2012); Ogbuokiri etal, (2014) in their respective research reports.

\section{Conclusion}

The effective use of palm oil sludge as animal feed will be of economic significance especially in view of the rising cost of imported feedstuffs. Palm oil sludge should be included in the broiler starter chicks at $12.5 \%$ level to enhance productivity and profitability and to reduce the cost of production.

\section{References}

Abdulmojeed, Y., Ayoade, J.A. and Dairu, Y.A., (2010). Effect of genotype and population density on growth performance, carcass characteristics and cost-benefits of broiler chickens in northcentral Nigeria. Trop. Ani. Health Prod. 42:719727.

Adeniji, A.A. and Jimoh, A., (2007). Effects of replacing maize with enzyme-supplemented bovine rumen content in the diets of pullet chicks. Int. J. Poult. Sci. 6:814-817. 4.

Adeniji, A. A. and Onyeleke, M. M., (2008). Effects of dictionary grit fed on the utilization of ruminant content by pullet chicks. J. Applied Sci. Res. 4(10): 1257-1260.

Allen, C.D., Russell, S.M. and Fletcher, D.L., (1997). The relationship of broiler breast meat colour and $\mathrm{pH}$ to shelf-life and odor development. Poult. Sci., 76(7): 1042-1046.

Alikwe, P.C.N., Olatunde, A.O. and Adarabioyo, M.I., (2011). Effect of palm oil mill exudate (POME) on the performance of broiler finishers. Res. J. of Poult. Sci., 4(1): 1-3.

Alu, S.E, Kaankuka, F.G., Bello, M. and Salau, E.S., (2013). Growth parameters and economic analysis of broiler finisher birds' production fed sugarcane scrapping meal (SCSM)-based diets. actaSATECH 4(2): $51-60$.

AOAC., (2001). Official methods of analysis, revised edition. Association of Analytical Chemists, Washington DC., USA.

Areola, O., Ahmed, K., Irueghe, O.J., Adeleke, B.O. and Leong, G.C., (2002). Certificate physical and human geography for senior secondary school: New Impression. University Press PLC, Ibadan, Nigeria.

Ayoade, J.A., Carew, S.N. and Ameh. A.E., (2007). The feed value of sugarcane scrapping meal for weaner rabbits: growth, meat yield, and cost of production. Proc. 32nd Ann. Conf. Nig. Soc. For Anim. Prod. NSAP) March 18th -21st, 2007 University of Calabar, Nigeria.

Bendich, A., (1989). Carotenoids and the immune response. J. Nutr. 119:112-115.

Bruce, F. N.D., (2015). The Palm oil Miracle. Coconut Research Center.

Burton, G. W., (1989). Antioxidant action of carotenoids. J. Nutr. 119:109-111.

Castaneda, M., Hirschler, E. and Sams, A., (2005). Skin pigmentation evaluation in broilers fed natural and synthetic pigments. Poult Sci. 84:143-7.

Coetzee, C., and Motshwi, A., (2014). ADVIT Animal Nutrition. Feed InfoNews Service, Johannesburg, South Africa.

Dada, A., (1999). Effect of palm oil sludge inclusion in broiler finisher ration. Proc. Annual Conference, Nigerian Soc. For Animal Prod., Ilorin, 23rd - 29th March, 1999.

Devendra, C., (1977). Utilization of feeding stuff from oil palm. Proc. National Workshop on Oil Palm By-Product Utilization. 14th-15thDecember, 1977, Kuala Lumpur, Malaysia. pp: 131 -166.

Devendra, C., (1988). Non-conventional feed resources and fibrous agricultural residues. Strategies for expanded utilization. Proceedings of a Consultation held in Hisar, India, 21-29 March 1988, IDRC, ICAR

Devendra, C., (1988). Non -conventional feed resources in Asia and the Pacific. Strategies for expanding and utilization at the small farm level, fourth edn. FAO/APHCA publication, Bangkok.

Devendra, C., and Fuller, M.F., (1979). Pig production in the tropics. Oxford Tropical Handbook. Oxford Uni. Press, Great Britain.

Devendra, C., Yeong, S.W., and Ong, H.K. (1982). The potential value of palm oil meal effluent (POME) as a feed source for farm animals in Malaysia. Proc. PORIM Workshop on oil palm yproducts utilization, 14-15th Dec. 1981, K. Lumpur, Malaysia, pp. 63-75.

Emaikwu, K. K., Chikwendu, D. O., and Sanni, A. S., (2011). Determinants of Flock Size in Broiler Production in Kaduna State of Nigeria. J. Agric. Ext. and Rural Dev., 3 (11): 202-211.

FAO., (2009). FAO FAOSTAT http://faostata.fao.org/default.htm Feltwell, R., and Fox, S., (1979). Practical poultry feeding, ELBS 1st Ed. Faber and Faber Ltd, London.

Gordon, S.P., and Gordon, F.S., (2004). Contemporary statistics. A computer approach. MCGraw Hill Publishers, New York, USA. 
Hencken, H., (1992). Chemical and physiological behavior of feed carotenoids and their effects on pigmentation. Poult. Sci., 71:711-717.

Hertrampt, J., (1988). Unconventional feedstuffs for livestock. Muhle +Mischfultertechnik, 125(9): 108-109.

Igwe, J.C., and Onyegbado, C.C., (2007). A review of palm oil mill effluent (POME) water treatment. Global J. of Environ. Res., 1(2): 54-62.

Liu, G.D., Hou, G.Y., Wang, D.J., Lv, X.J., Zhang, W.P., and Sun, Y.Y., (2008). Skin pigmentation evaluation in broilers fed different levels of natural okra and synthetic pigments. J. Appl. Poult. Res.:17:498-504.

Lokaewmanee, K., Yamauchi, K., Komori, T., and Saito, K., (2011). Enhancement of yolk color in raw and boiled egg yolk with lutein from marigold flower meal and marigold flower extract. J. Poult. Sci.: 48:25-32.

North, M.O., (1984). Commercial chicken production manual, third edn. Avi Publishing Company, Inc. West Point, Connecticut.

Ogbuokiri, U.D.E., (2012). Effect of total replacement of maize with cassava and cassava production on the skin pigmentation of broiler chickens. Ani. Prod. Res. Adv., 8(1): 20-24.

Ogbuokiri, U.D.E., Iheanacho, A.L., Osuji, A.L., Okoli, I.C., and Ekenyem, B.U., (2014). Effect of pawpaw leaf (Carica papaya, Linn.) meal on some performance attributes of starter broiler chicks. J. Anim. Sci. Adv., 4(5): 826-832.

Oluyemi J.A., and Robert, F.A., (2002). Poultry production in warm wet climates, second edn, published by Macmillan publishers limited, London

Opara, C.C., (1996). Studies on the use of Alchornia cordifolia leaf meal as a feed ingredient in poultry diets. MSc Thesis, Federal University of Technology, Owerri, Nigeria.

Pauzenga, U., (1985). Feeding parent stock.

Zootecnica International, 14: 22-24.

Ouart, M. D., Bell, D. E., Janky, D. M., Dukes, M. G., and Marion, J. E. (1988). Influence of source and physical form of xanthophyll pigment on broiler pigmentation and performance. Poultry Sci. 67:544-548.

Raghavan, V., (2001). Feed Mix. Vol. 9 No. 3 Ranjhnan, S.K., (2001). Animal nutrition in the tropics. Vikas Publication House, PVT ITO. New Delhi. Vol.5:31-58.

Schiedt, K., (1998). Absorption and metabolism of carotenoids in birds, fish and crustaceans. Pages 285-358 in Biosynthesis and Metabolism. Carotenoids. Vol. 3.

Steel, S.O.C., and Torrie, J.H., (1980). Principal and procedures of statistics. McGraw Hill Co. Inc., New York.

Sunde, M. L., (1992). The scientific way to pigment poultry products. Poult. Sci. 71:709-710.
Tewe, O.O., (2004). Cassava for livestock feed in subSaharan Africa. The Global Cassava Development Strategy in IFAD/FAO in Rome, p 64.

Tyczkowski, J., Schaeffer. J. L., and Hamilton, P. B., (1991). Measurement of mal-absorption of carotenoids in chickens with pale bird syndrome. Poult. Sci. 70:2275-2279.

Udedibie, A.B.I., (1987). Comparative evaluation of leaf of pawpaw (C. papaya), Jack bean ( $C$. ensiformis), sword bean ( $C$. gladiata) and pigeon pea $(C$. cajan) as feed ingredients and yolk coloring agents in laying diets. Nig. J. Anim. Prod., 14: 61-66.

Velasco, V., and Williams, P., (2011). Improving meat quality through natural antioxidants. Chil $\mathrm{J}$ Agr, Res.:71:313-22.

Vuilleumier, J.P., (1969). The "Roche yolk color fan" - An instrument for measuring yolk color. Poult. Sci., 48: 767- 779.

Waller, A., (2007). An economic approach to broiler production. Poultry International. The Poultry Site.

Yusuf, A.I., Tukur, H.M., Abubakar, A., and Olorede, B.R., (2009). Effect of feeding diets containing varying energy levels on the performance of growing pullets in a semi-arid environment. Trop. J. Anim. Sc. vol. 11:40-46. 